\title{
Production of fructooligosaccharides and $\beta$-fructofuranosidase by batch and repeated batch fermentation with immobilized cells of Penicillium expansum
}

\author{
Solange I. Mussatto $\cdot$ Margarida B. Prata $\cdot$ \\ Lígia R. Rodrigues $\cdot$ José A. Teixeira
}

Received: 25 January 2012/Revised: 20 March 2012/Accepted: 25 March 2012/Published online: 20 April 2012

(C) Springer-Verlag 2012

\begin{abstract}
The production of fructooligosaccharides (FOS) and $\beta$-fructofuranosidase (FFase) by immobilized cells of Penicillium expansum was evaluated. In an initial stage, different low-cost materials including synthetic fiber, polyurethane foam, stainless steel sponge, loofah sponge, and cork oak were tested as carrier for the fungus immobilization. Additionally, the influence of the inoculum age ( 1 or 3 weeks) on cells immobilization, FOS and FFase production was also verified. Synthetic fiber and polyurethane foam were the best materials for $P$. expansum immobilization (2.21 and $1.98 \mathrm{~g} / \mathrm{g}$ carrier, respectively) and FOS production (120.3 and $104.8 \mathrm{~g} / \mathrm{l})$, and gave also high results of FFase activity (23.01 and $32.42 \mathrm{U} / \mathrm{ml}$ ). Then, the production of FOS and FFase by repeated batch fermentation with $P$. expansum immobilized on synthetic fiber was studied, aiming to improve the batch fermentation results. The results obtained in this stage were very promising with FOS yields of 87,72 , and $44 \%$, in the 3 initial cycles $(60 \mathrm{~h})$, respectively; the FFase activity was constant throughout the process ( 6 cycles, $96 \mathrm{~h}$ ). Repeated batch fermentation with immobilized cells of $P$. expansum was found as being a technology with great potential for FOS and FFase production on industrial scale.
\end{abstract}

S. I. Mussatto $(\bowtie) \cdot$ M. B. Prata $\cdot$ L. R. Rodrigues ·

J. A. Teixeira

Institute for Biotechnology and Bioengineering (IBB), Centre of Biological Engineering, University of Minho, Campus Gualtar, 4710-057 Braga, Portugal

e-mail: solange@deb.uminho.pt; solangemussatto@hotmail.com

M. B. Prata

Department of Chemistry, FCUP-Sciences Faculty, University of Porto, Porto, Portugal
Keywords Fructooligosaccharides · $\beta$-Fructofuranosidase $\cdot$ Immobilized cells $\cdot$ Penicillium expansum $\cdot$ Repeated batch

\section{Introduction}

Fructooligosaccharides (FOS) are fructose oligomers that cannot be hydrolyzed by the gastrointestinal enzymes [1] and that are regarded as prebiotic since they selectively stimulate the growth and/or activity of bifidobacteria and lactobacilli [2, 3], which are the microorganisms responsible for promoting benefits for the human's health. Therefore, it has been observed in the past few years a growing demand on FOS utilization by the food industry.

FOS are mainly composed of 1-kestose, 1-nystose, and 1 - $\beta$-fructofuranosyl nystose, which can be found in many fruits and vegetables, although in very low concentrations to exert any beneficial effect, and its production is limited by seasonal conditions $[1,4]$. Thus, extraction procedures to obtain these compounds are not viable, and the FOS production on an industrial level is required. On industrial scale, FOS are produced either from sucrose by transfructosylation with fructosyltransferase enzymes or from inulin by controlled enzymatic hydrolysis with endoinulinases $[5,6]$. The companies that commercially manufacture FOS were summarized in a recent study [6]. FOS have been produced from sucrose by Beghin-Meiji Industries, France (Actilight), Cheil Foods and Chemicals Inc., Korea (OligoSugar), GTC Nutrition, USA (Nutra-Flora), Meiji Seika Kaisha Ltd., Japan (Meioligo), and Victory Biology Engineering Co. Ltd., China (Prebiovis scFOS), while the commercial production of FOS from inulin has been done by the companies Orafti Active Food Ingredients, USA (Raftilose), Beneo-Orafti, Belgium (Orafti), Cosuera Group 
Warcoing, Belgium (Fibrulose), and Jarrow Formulas, USA (Inulin FOS).

When comparing the two different processes for FOS production (from sucrose or inulin), the transfructosylation process is considered to have a greater potential because it is possible to synthesize FOS oligomers of defined chain length or to obtain desired composition mixtures by controlling the reaction time [5]. Fructosyltransferase enzymes can be derived from plants, bacteria, or fungi, the last having higher transfructosylating activity $[1,7]$. However, the yields of transfructosylation reactions are usually low (55-60\%) [1], and the development of a more economically viable process for the production of FOS is desired. Although many studies have been carried out to attain this purpose, up to date, no relevant results capable of replacing the industrial process were obtained, and the search for new methods to improve the FOS yield is still a big challenge.

Our research group has been focused in finding an efficient process for FOS and $\beta$-fructofuranosidase (FFase, enzyme with hydrolysis and transfructosylation activity) production able to be used in industrial scale [8-10]. Although several Aspergillus japonicus strains have been reported as potentially adequate for industrial production of FOS [11], Penicillium expansum was recently found as being a fungal strain of great potential for FOS production from sucrose [12]. Despite the fact that the utilization of immobilized microorganisms as biocatalysts for the production of antibiotics, organic acids, and enzymes has been already extensively studied, there are few reports on the use of these systems for FOS production, and there is not any published study about the FOS production by immobilized $P$. expansum.

The use of immobilized cell systems is considered a more promissory and advantageous alternative when compared to free cell systems, for several reasons as follows: (i) It promotes the increase in biomass concentration that leads to an improvement in the process efficiency and productivity [13]; (ii) viscosity problems caused by certain fungi morphologies, responsible for mass transfer limitations, are eliminated [14]; (iii) it makes easier the biomass reutilization and separation from the fermented broth [15, 16]. There are several immobilization techniques, and the right choice of the immobilization method and the type of carrier are crucial factors for the development of an efficient system [8, 17]. Additionally, the fermentation operation mode also influences the process efficiency, with repeated batch being a well-known method for enhancing the productivity of microbial cultures [18-20]. The use of immobilized cell systems is particularly feasible for repeated batch fermentation because it facilitates the biomass recovery for use in the subsequent batches.

The present study evaluated the production of FOS and FFase by immobilized cells of $P$. expansum. Initially, five low-cost materials including synthetic fiber, polyurethane foam, stainless steel sponge, loofah sponge, and cork oak were evaluated, and the best material carrier for the cells immobilization, FOS and FFase production, was selected. Then, assays using the fungal strain immobilized in the selected material were carried out through repeated batch operation mode aiming to maximize the batch fermentation results.

\section{Materials and methods}

Microorganism and inoculum preparation

Penicillium expansum MUM 02.14 (from Micoteca of the Centre of Biological Engineering, University of Minho) was the fungus used in the experiments. The strain was maintained at $4{ }^{\circ} \mathrm{C}$ on plates containing potato dextrose agar (PDA, Difco). For the production of spores, it was grown on PDA medium, at $22-25^{\circ} \mathrm{C}$ [12], during 1 or 3 weeks, except for the repeated batch fermentation assays, which used spores obtained after the strain cultivation during 1 week. The inoculum for use in the experiments was obtained by suspension of the produced spores in sterilized solution of $0.1 \%(\mathrm{w} / \mathrm{v})$ Tween 80 and adjustment to the desired concentration by counting in a Neubauer chamber.

\section{Carriers' preparation}

Three inorganic materials, such as synthetic fiber (SF), polyurethane foam (PF), and stainless steel sponge (SS) (all of them from Scotch Brite, 3 M Spain, SA), and two lignocellulosic materials, such as loofah sponge (LS), and cork oak (CO), were tested as carrier for the cells immobilization. To be used in the experiments, they were cut to particle sizes of approximately $3 \times 3 \mathrm{~mm}$ (length $\times$ width), boiled for $10 \mathrm{~min}$, washed three times with distilled water, dried at $60{ }^{\circ} \mathrm{C}$, and sterilized at $121{ }^{\circ} \mathrm{C}$ for $20 \mathrm{~min}$.

Media and fermentation conditions

Assays for the selection of the material carrier and evaluation of the inoculum age were carried out in $500-\mathrm{ml}$ Erlenmeyer flasks containing $1 \mathrm{~g}$ of the sterilized immobilization carrier and $100 \mathrm{ml}$ of culture medium with the following composition $(\% \mathrm{w} / \mathrm{v})$ : sucrose, 20.0 ; yeast extract, 2.75; $\mathrm{NaNO}_{3}, 0.2 ; \mathrm{MgSO}_{4} \times 7 \mathrm{H}_{2} \mathrm{O}, 0.05 ; \mathrm{K}_{2} \mathrm{HPO}_{4}$, 0.5 ; and $\mathrm{KCl}, 0.05$. Steam sterilization of the medium was carried out at $112{ }^{\circ} \mathrm{C}$ for $15 \mathrm{~min}$. Some fermentation assays were also performed without the carrier addition, in order to compare the performance between free and immobilized cells. All the flasks were aseptically inoculated with $1.0 \mathrm{ml}$ 
of a spore suspension containing $1.8 \times 10^{7}$ spores $/ \mathrm{ml}$ and incubated in a rotary shaker at $25{ }^{\circ} \mathrm{C}$ and $160 \mathrm{rpm}$ for $48 \mathrm{~h}$. Cells were immobilized in situ in the flasks by natural adsorption through their direct contact with the carrier at the beginning of each fermentation run. To evaluate the influence of inoculum age, the experiments were conducted with $P$. expansum grown during 1 or 3 weeks in PDA medium at $22-25{ }^{\circ} \mathrm{C}$. The $\mathrm{pH}$ of the media was not controlled during the experiments, being gradually decreased from 7.0 (at the beginning of the processes) to 6.0 (at the end of the fermentations). During the fermentations, samples were aseptically collected and filtered through $0.2-\mu \mathrm{m}$ sterile cellulose membranes to remove any free cells from the liquid culture. The filtered fermentation broth was used for FOS, residual sugars, and FFase activity quantification.

Repeated batch fermentation experiments were also carried out in 500-ml Erlenmeyer flasks containing $1 \mathrm{~g}$ of the sterilized immobilization material and $100 \mathrm{ml}$ of culture medium (the same previously described). All the flasks were inoculated with $1.0 \mathrm{ml}$ of a spore suspension containing $1.8 \times 10^{7}$ spores $/ \mathrm{ml}$ and incubated in a rotary shaker at $25{ }^{\circ} \mathrm{C}$ and $160 \mathrm{rpm}$ for $96 \mathrm{~h}$. After the initial $36 \mathrm{~h}$ (duration of the first cycle), the fermented broth was replaced by fresh medium each $12 \mathrm{~h}$ until completion of a total of 6 cycles ( $96 \mathrm{~h}$ of fermentation). Since the cells were mostly immobilized in the support material, the fermented broth separation could be easily done by decantation. Samples were collected at the end of each cycle, filtered through $0.2-\mu \mathrm{m}$ sterile cellulose membranes, and the fermentation broth was used for FOS, residual sugars, and FFase activity quantification.

\section{Analytical methods}

Concentration of free and immobilized cells was determined at the end of the fermentations. Free cells concentration $(\mathrm{g} / \mathrm{l})$ was determined after drying at $105^{\circ} \mathrm{C}$ until constant weight. The difference between membrane weight and membrane with filtered cells gave the mass of cells that were not able to immobilize into the carrier. The concentration value was calculated considering the volume of filtered fermentation medium. Immobilized cells ( $\mathrm{g} / \mathrm{g}$ carrier) were determined after washing the carriers three times with distilled water and drying at $105{ }^{\circ} \mathrm{C}$ until constant weight. The biomass dry weight was calculated from the difference between the mycelium plus carrier and the carrier itself.

FOS (1-kestose, 1-nystose, and 1- $\beta$-fructofuranosyl nystose) and residual sugars (sucrose, fructose, and glucose) were analyzed using high-performance liquid chromatography (HPLC) [9] on an equipment LC-10 A (Jasco, Japan) with a Prevail Carbohydrate ES column $(5 \mu \mathrm{m}$, $250 \times 4.6 \mathrm{~mm}$, Alltech) at room temperature and a refractive index detector. The response of the refractive index detector was recorded and integrated using the Star Chromatography Workstation software (Varian). A mixture of acetonitrile and $0.04 \%$ ammonium hydroxide in water $(70 / 30 \mathrm{v} / \mathrm{v})$ was used as mobile phase at a flow rate of $1.0 \mathrm{ml} / \mathrm{min}$. Before injection, the samples were filtered through $0.2-\mu \mathrm{m}$ filters and diluted with Milli-Q water when needed. The sugars and FOS concentrations were determined from standard curves made with known concentrations of each compound. The yields of total FOS produced (sum of 1-kestose, 1-nystose, and 1- $\beta$-fructofuranosyl nystose) were calculated taking into account the initial sucrose concentration $\left(Y_{\mathrm{P} / \mathrm{St}}, \mathrm{g} / \mathrm{g}\right)$ and the sucrose consumed along the fermentation $\left(Y_{\mathrm{P} / \mathrm{Sc}}, \mathrm{g} / \mathrm{g}\right)$. FOS volumetric productivity $\left(Q_{\mathrm{P}}, \mathrm{g} / \mathrm{l} . \mathrm{h}\right)$ was calculated by the ratio between the total FOS produced $(\mathrm{g} / \mathrm{l})$ and fermentation time $(\mathrm{h})$.

The $\beta$-fructofuranosidase (FFase) activity was determined by quantification of the glucose released from sucrose, as previously described [9]. The reaction mixture contained $100 \mathrm{ml}$ of the crude FFase extract, $300 \mathrm{mmol}$ of sucrose and $50 \mathrm{mmol}$ of sodium acetate buffer ( $\mathrm{pH} 5.0)$ in a total volume of $1 \mathrm{ml}$. After incubation for $20 \mathrm{~min}$ at $30^{\circ} \mathrm{C}$, the reaction was stopped by heating for $5 \mathrm{~min}$ at $100^{\circ} \mathrm{C}$. After cooling, the amount of glucose released into the supernatant was measured by HPLC (see above). One unit (U) of the FFase activity was defined as the amount of enzyme required to release $1 \mu \mathrm{mol}$ of glucose per min, from sucrose under the above conditions.

Photographs by scanning electron microscopy (SEM) of synthetic fiber, polyurethane foam, and stainless steel sponge were obtained from a Leica Cambridge S360 microscope. Before examination, samples were dried and sputter-coated with gold, and maintained under vacuum conditions. Each sample was observed with magnifications of 20 -fold and 150 -fold.

\section{Statistical analysis}

All the fermentation experiments were conducted at least in duplicate, and average values are reported. The results were statistically analyzed by using the Tukey's range test, where a $p$ value of less than 0.05 was regarded as significantly different. Statgraphics Plus for Windows, version 4.1, was the software used for data analysis.

\section{Results and discussion}

Influence of inoculum age on cell immobilization, FOS production and enzymatic activity

Obtaining an inoculum in the exponential growth phase is essential for a fast microorganism growth after inoculation 
in the fermentation medium. Cultures below this phase or beyond it could lead to lag phases of undefined lengths and the production of secondary metabolites non-essential to cell growth [21, 22]. For this reason, the influence of inoculum age ( 1 or 3 weeks) on $P$. expansum immobilization, FOS and FFase production was evaluated in a first step. Statistical analysis of the obtained data (Table 1) revealed no significant differences (at $95 \%$ confidence level), neither on immobilization nor on FOS production, when $P$. expansum cultivated during 1 or 3 weeks was used as inoculum. The only difference verified concerning the two inoculum age was related to the FFase activity in the presence of SF, where the highest values of enzymatic activity were obtained for the 3 -week inoculum. Nonetheless, this high FFase activity value was not a synonym of higher FOS production, suggesting that this enzyme was with an elevated hydrolysis activity $\left(U_{\mathrm{h}}\right)$, since it presents both transfructosylating and hydrolyzing activities $\left(U_{\mathrm{t}}\right.$ and $U_{\mathrm{h}}$, respectively) [23]. Regarding the fermentative parameters $\left(Y_{\mathrm{P} / \mathrm{St}}, Y_{\mathrm{P} / \mathrm{Sc}}\right.$, and $\left.Q_{\mathrm{P}}\right)$, only the FOS volumetric productivity $\left(Q_{\mathrm{P}}\right)$ on $\mathrm{PF}$ showed statistically significant difference between the experiments carried out with the inoculum grown for 1 or 3 weeks. Despite these two differences shown by the statistical analysis, it can be concluded that 1 week is an enough time for the inoculum cultivation to attain high cells immobilization and FOS production by $P$. expansum. One week was also considered the best inoculum age for the cultivation of other microorganisms [24-26].

Selection of the carrier for immobilization and FOS production by $P$. expansum

Free and immobilized cell concentrations of $P$. expansum on the five different carriers are represented in Table 2. It can be noted that the fungus had a higher adhesion into the inorganic carriers (SF, PF and SS) than in the lignocellulosic materials (LS and CO). In addition, in these three cases the fermentation media were clearer since they presented less suspended free cells, while the media where the immobilization was inefficient (LS and CO) had more free cells in suspension. Besides immobilizing in a larger extent, the total cell growth in the media containing inorganic carriers was higher (Table 2), which is in agreement with Cohen [13] who refers that immobilization increases biomass growth, when compared to the medium containing only free cells in suspension. Despite the similarity to the free cells medium (which gave $14.08 \mathrm{~g}$ cells/l), cell growth on the media containing SS and CO did not occur at the same extent as those verified on media with SF or PF. On the other hand, the lower total growth was observed on medium containing LS (7.36 g/l), which could be related to a possible release of toxic compounds from the carrier and inhibition of these compounds on the microorganism growth.

In a general form, FOS production was maximal at $48 \mathrm{~h}$ of fermentation, with the exception of the media containing $\mathrm{CO}$ and without carrier (free cells) that had a similar performance with the maximum FOS production occurring at $36 \mathrm{~h}$ (Fig. 1). This similar behavior could be due to the fact that the medium containing $\mathrm{CO}$ presented more free cells in suspension $(11.31 \mathrm{~g} / \mathrm{l})$ than the media containing the other carriers. Therefore, bioconversion of sucrose into FOS occurred at the same extent as in the medium containing only free cells, which gave $14.08 \mathrm{~g} / \mathrm{l}$ of total cells concentration.

Immobilization results, FOS production, and FFase activity by $P$. expansum immobilized on different carriers are presented in Table 3, which also shows the statistically significant differences between samples, at $95 \%$ confidence level, according to a multiple comparison analysis. According to this analysis, the inorganic carriers SF and PF gave similar fermentation results for all the analyzed parameters, as well as verified for the pair of lignocellulosic carriers (LS and CO).

Concerning the cell immobilization, SF and PF gave the highest results, being different $(p<0.05)$ from those achieved with the other carriers. This result suggests a good potential of applicability of SF or PF in repeated batch or continuous fermentation processes. Despite the fact that SS had attached less cells than these two inorganic carriers (difference significant at $95 \%$ confidence level), the obtained immobilization results were even better than those attained for the lignocellulosic carriers (LS and CO). SS has been reported as an excellent material for the immobilization of Trametes hirsuta during the laccase production for the degradation of textile dyes [17]. In the present work, this material also revealed ability to immobilize the fungus $P$. expansum during FOS production. Nevertheless, its results were not as high as the ones obtained with SF and PF, probably due to its smooth surface (Fig. 2e, f), which was not so adequate for the fungus attachment. According to Kosaric and Blaszczyk [27], microorganisms tend to form thin layers on smooth surfaces, being easily destroyed by the normal agitation conditions. Conversely, the great immobilization results achieved with SF and PF carriers can be related to their rough and porous structures (Fig. 2a-d), which, besides increasing the surface area, allow the microorganisms to attach more firmly, since the environment becomes more hydrodynamically stable. This, consequently, reduces the detachment of immobilized cells by hydraulic shearing forces $[13,28]$, which was corroborated by the clear fermentation media obtained for the SF and PF materials. Similar results were achieved by Guimarães et al. [29], who verified that the porous structures of PF and SF gathered the best colonization characteristics/ 


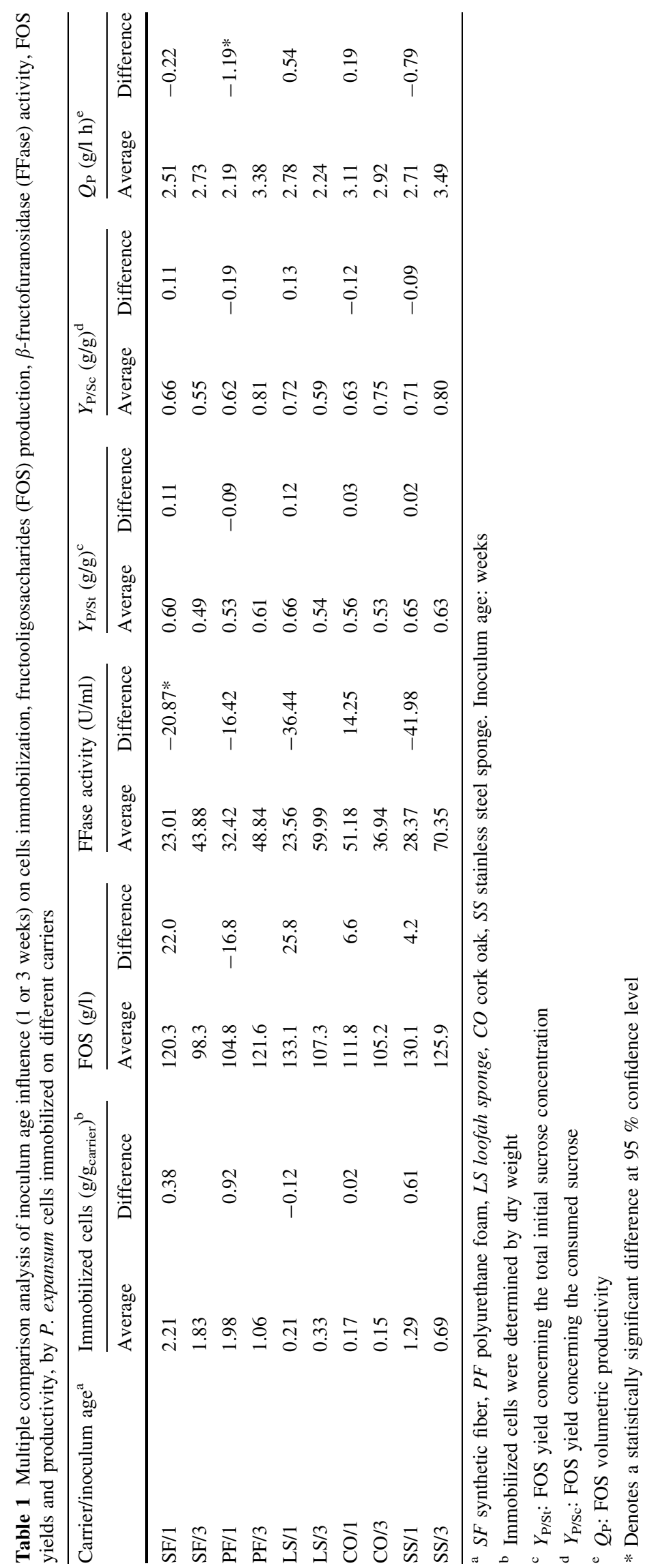


Table 2 Concentration of cells in the free form and immobilized on different carriers, after $48 \mathrm{~h}$ of sucrose fermentation by $P$. expansum

\begin{tabular}{llll}
\hline Carrier & $\begin{array}{l}\text { Immobilized } \\
\text { cells } \\
(\mathrm{g} / \mathrm{g} \text { carrier })\end{array}$ & $\begin{array}{l}\text { Free cells } \\
(\mathrm{g} / \mathrm{l})\end{array}$ & $\begin{array}{l}\text { Total cells } \\
(\mathrm{g} / \mathrm{l})\end{array}$ \\
\hline $\begin{array}{l}\text { Synthetic fiber-SF } \\
\begin{array}{l}\text { Polyurethane } \\
\text { foam—PF }\end{array}\end{array}$ & 2.21 & 0.96 & 23.06 \\
$\begin{array}{l}\text { Stainless steel } \\
\text { sponge—SS }\end{array}$ & 1.98 & 0.61 & 20.41 \\
$\begin{array}{l}\text { Loofah sponge-LS } \\
\text { Cork oak-CO }\end{array}$ & 0.21 & 0.49 & 13.39 \\
\hline
\end{tabular}

Free and immobilized cells were determined by dry weight

${ }^{\text {a }}$ Free cells + immobilized cells on the $100 \mathrm{ml}$ of fermentation medium

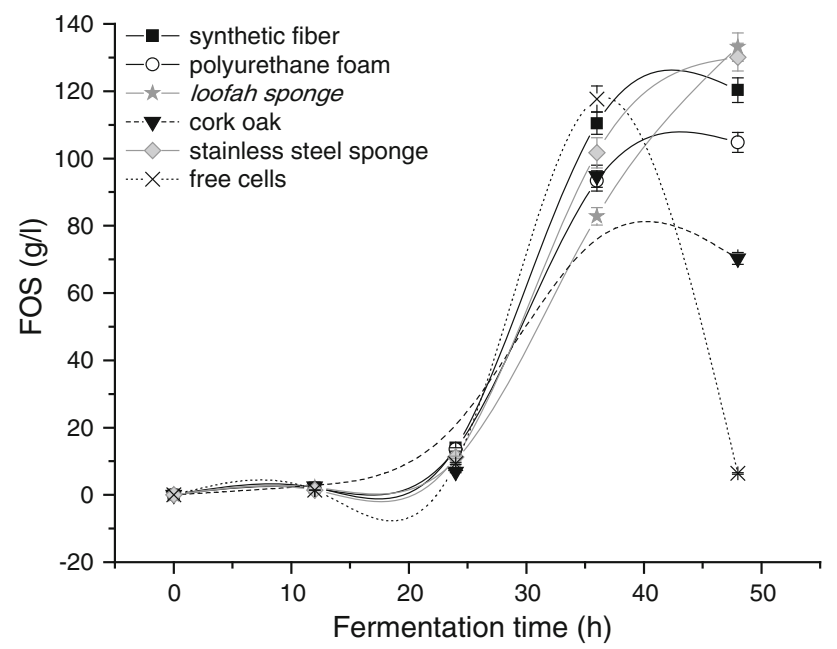

Fig. 1 Fructooligosaccharides (FOS) production by $P$. expansum immobilized (or not) on different materials

properties for the attachment of the Phanerochaete chrysosporium mycelia, when compared to immobilization on SS.

When comparing all the studied materials, lignocellulosic carriers had the poorest performance regarding cell immobilization of $P$. expansum. In a similar way, during the production of xylanase by immobilized cells of Bacillus pumilus, the inorganic carriers (SF and $\mathrm{PF}$ ) were also more efficient when compared to the natural ones (cotton and silk) [30]. The low immobilization results verified on cork oak could be explained by its contents of extractives (responsible for its permeability properties) and/or phenolic compounds (character toxic for the microorganisms) [31], which might had interfered in the adhesion capacity of the P. expansum cells into the carrier. On the other hand, the low immobilization results observed for LS could be related to the simple pre-treatment performed (only boiling). Coelho [32] reported that LS treatment with vapor altered the material's structure and favored the immobilization of Candida guilliermondii.

Concerning the maximum FOS production yield $\left(Y_{\mathrm{P} / \mathrm{St}}\right)$, volumetric productivity $\left(Q_{\mathrm{P}}\right)$, and enzymatic activity of FFase, the obtained results did not differ at $95 \%$ confidence level for the different carriers used (Table 3). Therefore, the next step of this study consisted in a comparison between FOS production results by free cells and immobilized in SF or PF (the most suitable materials for P. expansum immobilization) (Table 4). When statistically compared, the results obtained for these three fermentation media did not show differences at $95 \%$ confidence level. However, maximum FOS production in free cells medium was achieved after $36 \mathrm{~h}$ of fermentation, while $48 \mathrm{~h}$ were necessary to obtain the maximum production in media containing cells immobilized in SF or PF, suggesting that microenvironmental conditions of immobilized cells may differ from free cells [33]. FOS production by free or immobilized cells did not differ also in terms of proportion of 1-kestose (GF2), 1-nystose (GF3), and 1- $\beta$-fructofuranosyl nystose (GF4) in the final mixture. Fermentation with free cells gave a final FOS mixture containing $72.1 \%$ GF2, $26.4 \%$ GF3 and $1.5 \%$ GF4, while fermentation with cells immobilized in SF or PF yielded FOS mixtures containing $74.2 \%$ GF2, $22.9 \%$ GF3 and $2.9 \%$ GF4; and

Table 3 Multiple comparison analysis of cells immobilization results, fructooligosaccharides (FOS) production and $\beta$-fructofuranosidase (FFase) activity, obtained by P. expansum immobilized on different carriers (inoculum age of 1 week)

\begin{tabular}{|c|c|c|c|c|c|}
\hline Carrier & Immobilization $(\mathrm{g} / \mathrm{g} \text { carrier })^{\mathrm{I}}$ & FOS $(g / l)$ & FFase activity (U/ml) & $Y_{\mathrm{P} / \mathrm{St}}(\mathrm{g} / \mathrm{g})^{\mathrm{II}}$ & $Q_{\mathrm{P}}(\mathrm{g} / \mathrm{l} \mathrm{h})^{\mathrm{III}}$ \\
\hline SF & $2.21^{\mathrm{c}}$ & $120.3^{\mathrm{ab}}$ & $23.01^{\mathrm{a}}$ & $0.60^{\mathrm{ab}}$ & $2.51^{\mathrm{ab}}$ \\
\hline $\mathrm{PF}$ & $1.98^{\mathrm{c}}$ & $104.8^{\mathrm{a}}$ & $32.42^{\mathrm{a}}$ & $0.53^{\mathrm{a}}$ & $2.19^{\mathrm{a}}$ \\
\hline SS & $1.29^{\mathrm{b}}$ & $130.1^{\mathrm{b}}$ & $28.37^{\mathrm{a}}$ & $0.65^{\mathrm{ab}}$ & $2.71^{\mathrm{abc}}$ \\
\hline LS & $0.21^{\mathrm{a}}$ & $133.1^{\mathrm{b}}$ & $23.56^{\mathrm{a}}$ & $0.66^{\mathrm{b}}$ & $2.78^{\mathrm{bc}}$ \\
\hline $\mathrm{CO}$ & $0.17^{\mathrm{a}}$ & $111.8^{\mathrm{ab}}$ & $51.18^{\mathrm{a}}$ & $0.56^{\mathrm{ab}}$ & $3.11^{\mathrm{c}}$ \\
\hline
\end{tabular}

Same letters denote no statistically significant differences between samples, at $95 \%$ confidence level

$S F$ synthetic fiber, $P F$ polyurethane foam, SS stainless steel sponge, LS loofah sponge, CO cork oak

${ }^{I}$ Immobilized cells were determined by dry weight

II $Y_{\mathrm{P} / \mathrm{St}}$ : FOS yield concerning the initial sucrose concentration

${ }^{\text {III }} Q_{\mathrm{P}}$ : FOS volumetric productivity 

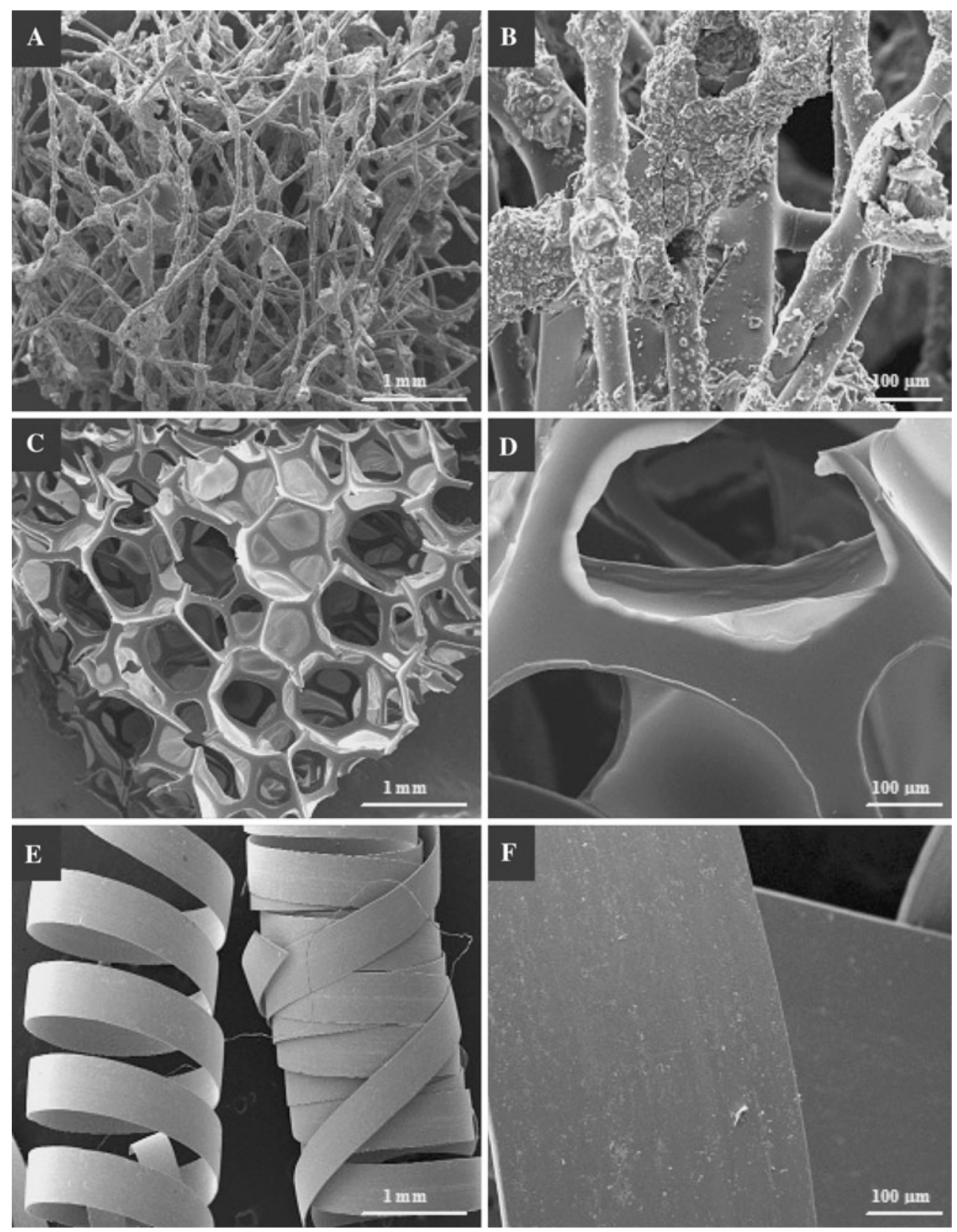

Fig. 2 Scanning electron microscopy (SEM) of synthetic fiber (a, b), polyurethane foam (c, d), and stainless steel sponge (e, f) samples. Magnification: 20-fold (scales of $1 \mathrm{~mm}$ ) and 150-fold (scales of $100 \mu \mathrm{m}$ )

$67.3 \% \mathrm{GF} 2,30.0 \% \mathrm{GF} 3$ and $2.7 \% \mathrm{GF} 4$, for SF and PF, respectively. In brief, it can be concluded that FOS production by cells immobilized on SF or PF was very efficient, allowing the reproduction of the results obtained in the free cells medium. This is advantageous for their application in repeated batch fermentation processes.

Repeated batch fermentation assays

The FOS yield and productivity obtained during the repeated batch fermentations are presented in Table 5. The maximum FOS production $(194.9 \mathrm{~g} / \mathrm{l})$ was reached at the end of the 1st cycle $(36 \mathrm{~h})$, giving a productivity $\left(Q_{\mathrm{P}}\right)$ of $5.41 \mathrm{~g} / \mathrm{l} \mathrm{h}$. This condition gave also small quantities of fructose and glucose as by-products of the reaction, with glucose concentration being $15 \%$ higher than fructose's, which denotes fructose use in FOS production. After replacing the fermentation medium, it was observed a reduction in FOS production of approximately $13 \%$ by the end of the second cycle ( $48 \mathrm{~h}$ ), even though they were still produced with high yields. Until the third cycle, $P$. expansum was capable of producing FOS with yields similar 
Table 4 Fructooligosaccharides (FOS) production and $\beta$-fructofuranosidase (FFase) activity by free or immobilized cells of $P$. expansum

\begin{tabular}{lcrr}
\hline Fermentative parameters $^{\mathrm{a}}$ & \multicolumn{2}{c}{ Immobilized cells } & \multicolumn{2}{c}{ Free cells } \\
\cline { 2 - 3 } & $\mathrm{SF}$ & 104.8 & 0.53 \\
\hline FOS maximum $(\mathrm{g} / \mathrm{l})$ & 120.3 & 0.62 & 0.58 \\
$Y_{\mathrm{P} / \mathrm{St}}(\mathrm{g} / \mathrm{g})$ & 0.60 & 2.19 & 0.68 \\
$Y_{\mathrm{P} / \mathrm{Sc}}(\mathrm{g} / \mathrm{g})$ & 0.65 & 32.42 & 3.25 \\
$Q_{\mathrm{P}}(\mathrm{g} / \mathrm{l} \mathrm{h})$ & 2.51 & 25.15 \\
FFase maximum activity $(\mathrm{U} / \mathrm{ml})$ & 23.01 & & 41.15 \\
\hline
\end{tabular}

$S F$ synthetic fiber, $P F$ polyurethane foam

${ }^{a} Y_{\mathrm{P} / \mathrm{St}}$ : FOS yield concerning the initial sucrose concentration, $Y_{\mathrm{P} / \mathrm{Sc}}$ : FOS yield concerning the consumed sucrose, $Q_{\mathrm{P}}$ : FOS volumetric productivity

Table 5 Results achieved during the repeated batch fermentation for fructooligosaccharides production by $P$. expansum

\begin{tabular}{llll}
\hline Cycle (h) & $Y_{\mathrm{P} / \mathrm{St}}(\mathrm{g} / \mathrm{g})$ & $Y_{\mathrm{P} / \mathrm{Sc}}(\mathrm{g} / \mathrm{g})$ & $Q_{\mathrm{P}}(\mathrm{g} / \mathrm{l} \mathrm{h})$ \\
\hline 1st (36) & 0.87 & 0.99 & 5.41 \\
2nd (48) & 0.72 & 0.77 & 3.42 \\
3rd (60) & 0.44 & 0.46 & 1.66 \\
4th (72) & 0.27 & 0.29 & 0.87 \\
5th (84) & 0.07 & 0.07 & 0.17 \\
6th (96) & 0.04 & 0.04 & 0.09 \\
\hline
\end{tabular}

$Y_{\mathrm{P} / \mathrm{St}}$ : FOS yield concerning the total initial sucrose concentration, $Y_{\mathrm{P} / \mathrm{Sc}}$ : FOS yield concerning the consumed sucrose, $Q_{\mathrm{P}}$ : FOS volumetric productivity

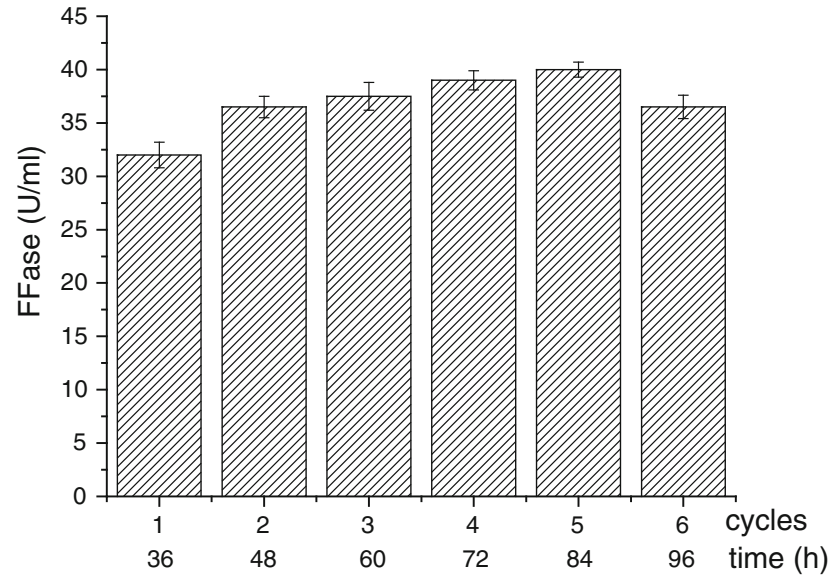

Fig. $3 \beta$-Frutofuranosidase (FFase) activity during the repeated batch fermentation with $P$. expansum immobilized on synthetic fiber

to the ones attained at an industrial scale (55-60\%) [1]. After that period, FOS production (and consequently the $Y_{\mathrm{P} / \mathrm{S}}$ and $Q_{\mathrm{P}}$ results) decreased more sharply, reaching similar values at the two last cycles $(86-96 \mathrm{~h})$, lower than $15 \mathrm{~g} / \mathrm{l}$. This can be due to an accumulation of dead cells, along the $96 \mathrm{~h}$ of process, caused by the biomass reuse [34]. Another possible explanation is the accumulation of secondary products resulting from cellular metabolism, such as ethanol or acetic acid (not quantified in this work), which could negatively influence the subsequent fermentation cycles. Cell wash with water before its reuse in the next cycle could be a solution for this problem [35].

Unlike the FOS production, FFase activity was practically constant throughout the fermentation process (Fig. 3) that is a very interesting result due to the industrial importance of this enzyme. Similar results were obtained by Mussatto et al. [9] during the FOS production by A. japonicus in repeated batch fermentations, where the synthesis of this oligosaccharide decreased along the cycles, while the FFase activity remained constant. Nevertheless, the FOS production by repeated batch fermentation with $P$. expansum (present study) gave better results than our previous study of FOS production by repeated batch fermentation with A. japonicus immobilized on SF [9], revealing the greater ability of $P$. expansum for use on the production of FOS.

Concerning the cell growth, it was observed a gradual growth of cells as a dense layer on the surface of the carrier, which covered the entire material at the end of the fermentation. It merits emphasizing that the reuse of the immobilized cells allowed eliminating the time required for the fungus growth (7 days), raising the FOS productivity, as a consequence. In other words, it requires 9 days ( 7 for cell growth and 2 for fermentation) to achieve the maximum values of FOS and FFase by $P$. expansum by the traditional batch fermentation; that is, 27 days would be required to carry out three individual batches, while only 
9.5 days were enough to perform three successive cycles under repeated batch fermentation conditions.

\section{Conclusions}

Penicillium expansum can be successfully immobilized in synthetic fiber or polyurethane foam and used for the production of FOS and FFase by fermentation. The use of this immobilized strain in repeated batch fermentations was demonstrated to be a process with great potential for application at an industrial scale, since substantial increases in the FOS yield and productivity were achieved (when compared to the values obtained under batch fermentation conditions) probably due to a reduction in substrate inhibition on transfructosylation process, and the FFase activity was obtained at elevated levels during a long fermentation time ( 6 cycles, $96 \mathrm{~h}$ ). These results are very promising and contribute for the development of a more efficient industrial process for FOS and FFase production.

It is worth mentioning that although several $P$. expansum strains have been reported as being producers of patulin, there is not any published study mentioning the production of this mycotoxin by $P$. expansum MUM 02.14 , and it is well known that the production of this toxin varies to each strain and with the conditions used for cultivation. This is an important aspect to be taken into account considering the use of this fungal strain for the production of FOS, which are compounds used for food purposes.

Acknowledgments The financial support from FCT, the Portuguese Foundation for Science and Technology (research grant SFRH/BPD/ $38212 / 2007$ ) is gratefully acknowledged.

Conflict of interest The authors declare that they have no conflict of interest.

\section{References}

1. Yun JW (1996) Fructooligosaccharides-occurrence, preparation, and application. Enzyme Microb Technol 19:107-117

2. Gibson GR, Roberfroid MB (1995) Dietary modulation of the human colonic microbiota: introducing the concept of prebiotics. J Nutr 125:1401-1412

3. Teitelbaum JE, Walker WA (2002) Nutritional impact of pre- and probiotics as protective gastrointestinal organisms. Annu Rev Nutr 22:107-138

4. Sangeetha PT, Ramesh MN, Prapulla SG (2005) Maximization of fructooligosaccharide production by two stage continuous process and its scale up. J Food Eng 68:57-64

5. Vega-Paulino RJ, Zúniga-Hansen ME (2012) Potential application of commercial enzyme preparations for industrial production of short-chain fructooligosaccharides. J Mol Catal B Enzym 76:44-51

6. Singh RS, Singh RP (2010) Production of fructooligosaccharides from inulin by endoinulinases and their prebiotic potential. Food Technol Biotechnol 48:435-450
7. Sangeetha PT, Ramesh MN, Prapulla SG (2005) Recent trends in the microbial production, analysis and application of fructooligosaccharides. Trends Food Sci Tech 16:442-457

8. Mussatto SI, Aguilar CN, Rodrigues LR, Teixeira JA (2009) Colonization of Aspergillus japonicus on synthetic materials and application to the production of fructooligosaccharides. Carbohydr Res 344:795-800

9. Mussatto SI, Rodrigues LR, Teixeira JA (2009) $\beta$-fructofuranosidase production by repeated batch fermentation with immobilized Aspergillus japonicus. J Ind Microbiol Biotechnol 36:923-928

10. Mussatto SI, Teixeira JA (2010) Increase in the fructooligosaccharides yield and productivity by solid-state fermentation with Aspergillus japonicus using agro-industrial residues as support and nutrient source. Biochem Eng J 53:154-157

11. Chien C-S, Lee W-C, Lin T-J (2001) Immobilization of Aspergillus japonicus by entrapping cells in gluten for production of fructooligosaccharides. Enzyme Microb Technol 29:252-257

12. Prata MB, Mussatto SI, Rodrigues LR, Teixeira JA (2010) Fructooligosaccharides production by Penicillium expansum. Biotechnol Lett 32:837-840

13. Cohen Y (2001) Biofiltration-the treatment of fluids by microorganisms immobilized into the filter bedding material: a review. Bioresour Technol 77:257-274

14. Papagianni M, Mattey M (2004) Physiological aspects of free and immobilized Aspergillus niger cultures producing citric acid under various glucose concentrations. Process Biochem 39:1963-1970

15. Santos JC, Mussatto SI, Dragone G, Converti A, Silva SS (2005) Evaluation of porous glass and zeolite as cells carriers for xylitol production from sugarcane bagasse hydrolysate. Biochem Eng $\mathbf{J}$ 23:1-9

16. Tieng YP, Sun G (2000) Use of polyvinyl alcohol as a cell entrapment matrix for copper biosorption by yeast cells. J Chem Technol Biot 75:541-546

17. Couto SR, Sanromán MA, Hofer D, Gubitz GM (2004) Stainless steel sponge: a novel carrier for the immobilization of the whiterot fungus Trametes hirsuta for decolourization of textile dyes. Bioresour Technol 95:67-72

18. Huang WC, Chen SJ, Chen TL (2008) Production of hyaluronic acid by repeated batch fermentation. Biochem Eng J 40:460-464

19. Radmann EM, Reinehr CO, Costa JAV (2007) Optimization of the repeated batch cultivation of Spirulina platensis in open raceway ponds. Aquaculture 265:118-126

20. Yang X, Wang B, Cui F, Tan T (2005) Production of lipase by repeated batch fermentation immobilized Rhizopus arrhizus. Process Biochem 40:2095-2103

21. Meyrath J, Suchanek G (1972) In: Norris JR, Ribbons DW (eds) Methods in microbiology. Academic Press, London

22. Stanbury PF, Whittaker A, Hall SJ (1995) Principles of fermentation technology, 2nd edn. Butterworth-Heinemann, Jordan Hill, Oxford

23. Hidaka K, Hirayama M, Sumi N (1988) A fructooligosaccharideproducing enzyme from Aspergillus niger ATCC 20611. Agric Biol Chem 52:1181-1187

24. Ganne KK, Dasari VRRK, Garapati HR (2008) Production of citric acid by Aspergillus niger MTCC 282 in submerged fermentation using Colocassia antiquorum. Res J Microbiol 3:150-156

25. Vergano MGF, Soria MA, Kerber NL (1996) Influence of inoculum preparation on citric acid production by Aspergillus niger. World J Microb Biot 12:655-656

26. Pelizer LH, Danesi EDG, Rangel CO, Sassano CEN, Carvalho JCM, Sato S, Moraes IO (2003) Influence of inoculum age and concentration in Spirulina platensis cultivation. J Food Eng 56:371-375

27. Kosaric N, Blaszczyk R (1990) In: Tyagi RD, Vembo K (eds) Wastewater treatment by immobilized cells. CRC Press, Boca Raton, Florida 
28. Quirynen M, Bollen CML (1995) The influence of surface roughness and surface free energy on supra- and subgingival plaque formation in man. J Clin Periodontol 22:1-14

29. Guimarães C, Matos C, Azeredo J, Mota M, Oliveira R (2002) The importance of the morphology and hydrophobicity of different carriers on the immobilization and sugar refinery effluent degradation activity of Phanerochaete chrysosporium. Biotechnol Lett 24:795-800

30. Mukesh K, Lavanya NM, Ramesh KC (2008) Cost-effective xylanase production from free and immobilized Bacillus pumilus strain MK001 and its application in saccharification of Prosopis juliflora. Biochem Eng J 38:88-97

31. Gil L (1998) Cortiça - Produção. Tecnologia e Aplicação, Editora INETI, Lisboa
32. Coelho TC (2007) Avaliação das condições de imobilização de células de Candida guilliermondii FTI 20037 em bucha vegetal (Luffa cylindrica) visando a produção de xilitol. MSc Thesis, University of São Paulo, Lorena/SP

33. Alteris E, Zueco J, Rico H, Sentandreu R, Parascandola P (1995) Electrophoretic mobility of external invertase from free and gel immobilized yeast cells. Res Microbiol 146:217-225

34. Meleigy SA, Khalaf MA (2009) Biosynthesis of gibberellic acid from milk permeate in repeated batch operation by a mutant Fusarium moliniforme cells immobilized on loofa sponge. Bioresour Technol 100:374-379

35. Liu Y, Liu D (2004) Kinetic study on glycerol production by repeated batch fermentation using free Candida krusei. Process Biochem 39:1507-1510 